\title{
Effect of Long Term Excessive Iodine Intake on Thyroid Function and Oxidative Stress in Euthyroid and Hypothyroid Rats
}

\author{
Amr M. Abbas ${ }^{1}$, Abd El-Aziz M. Hussein ${ }^{1}$, Gehan A. El Wakil, \\ Ayman Z. Elsamanoudy², Aza Abd El Aziz ${ }^{3}$ \\ Departments of Medical Physiology ${ }^{1}$, Medical Biochemistry ${ }^{2}$ \\ and Pathology ${ }^{3}$ Faculty of Medicine, Mansoura University, Egypt
}

\begin{abstract}
Background and aim of work: The aim of the current study was to investigate the effects of long term excessive iodine intake on gene expression of thyroidal sodium iodide symporter (NIS), D1 deiodinase and thyroid peroxidase (TPO), thyroid hormones, oxidative injury and anti-oxidative ability of euthyroid and hypothyroid Sprague Dawley rats. Materials and Methods: Ninety rats were divided into euthyroid and hypothyroid (thiocyanate induced) groups with or without administration of excess iodine (3000 or $6000 \mu \mathrm{g} / \mathrm{l}$ ) for 4 weeks. Serum thyroxine $\left(T_{4}\right)$, triiodothyronine $\left(T_{3}\right)$, TSH, thyroid antioxidants ((glutathione $S$ transferase, catalase, superoxide dismutase enzymes, nitric oxide and total antioxidants), lipid peroxide (malondialdehyde, MDA) were measured. RT-PCR gene expression for thyroidal NIS, D1 deiodinase and TPO were performed. Results: Thiocyanate significantly decreased thyroid hormones $\left(T_{3}, T_{4}\right)$, increased lipid peroxides and antioxidants, increased gene expression of NIS, D1 deiodinase, TPO. High iodine intake to hypothyroid rats significantly decreased NIS, DI deiodinase and TPO genes expression. Excess iodine significantly increased MDA and antioxidants in euthyroid and hypothyroid rats. Despite the increase in $T_{4}$ in euthyroid rats administered excess iodine, $T_{3}$ decreased whereas in hypothyroid rats, both of them were increased. NIS, and D1 deiodinase genes expression in euthyroid rats administered excess iodine were decreased but TPO was non-significantly increased. Conclusion: Hypothyroidism increased gene expression of NIS, TPO, and induces an oxidative stress. High iodine intake decreased NIS and DI deiodinase gene expression in euthyroid and hypothyroid rats. Moreover, excess iodine increase thyroid hormones, lipid peroxides and antioxidants in cases of euthyroid and hypothyroid rats. Therefore, screening of thyroid function and assessment of prooxidant/antioxidant status in subjects treated with drugs containing iodine and after investigations with contrast media are recommended.
\end{abstract}

Key words: excess iodine, thyroid hormones, oxidative stress, euthyroid, hypothyroid 


\section{INTRODUCTION}

The goal of eliminating iodine deficiency disease (IDD) has been achieved since Universal Salt Iodization (USI) policy has been widely carried out in many nations ${ }^{(\mathbf{1})}$. On the other hand, reports are increasingly appearing on the toxic effects caused by high amounts of iodine intake. Exposure to high amounts of iodine occurs via food, drinking water, medication and iodized salt or iodinated oil (2). Besides goiter, high amounts of iodine intake may increase the risk of hyperthyroidism, hypothyroidism, iodine-induced autoimmunity and thyroid cancer ${ }^{(3)}$.

A normal thyroid status is dependent on the presence of iodine which is a trace element necessary for the synthesis and metabolism of thyroid hormones. Because iodide is a major substrate of the synthesis of thyroid hormones thyroxine $\left(\mathrm{T}_{4}\right)$ and 3,3',5-tri-iodothyronine deficiency is an important health problem in areas with iodine-deficient soil ${ }^{(4)}$.Thyroid hormone synthesis requires the generation of $\mathrm{H}_{2} \mathrm{O}_{2}$ as cosubstrate which could be the source of reactive oxygen species (ROS) ${ }^{(5)}$. The basic steps in the process of synthesis of $T_{3}$ and $T_{4}$ include active iodide transport into thyrocytes via the sodium iodide symporter (NIS) ${ }^{(6)}$ at basolateral membrane and its translocation into the follicular lumen probably via pendrin, an iodide/chloride transporter present in the apical membrane ${ }^{(7)}$. On the outer site of apical surface, iodide is rapidly oxidized and incorporated into tyrosyl residues in thyroglobulin $(\mathrm{Tg}){ }^{(8)}$. This process is catalyzed by thyroid peroxidase (TPO) in the presence of an $\mathrm{H}_{2} \mathrm{O}_{2}$-generating system. $\mathrm{H}_{2} \mathrm{O}_{2}$ is formed from the oxidation of nicotinamide adenine dinucleotide phosphate by a thyroidal nicotinamide adenine dinucleotide phosphate oxidase (Thox2 or Duox2), a 1548amino acid integral membrane flavoprotein ${ }^{(9)}$. Iodine, in an oxidized form, can inhibit its own organification by TPO, a process known as the Wolff-Chaikoff effect, by inhibiting $\mathrm{H}_{2} \mathrm{O}_{2}$ production, perhaps via reducing the availability of the mature Duox 2 protein ${ }^{(5)}$. The pituitary-derived TSH, interacting with its receptor (TSHR) at the basolateral membrane of thyrocytes is the main regulator of thyroid hormone synthesis ${ }^{(8)}$.

Oxidative stress is a general term used to describe a state of damage caused by reactive oxygen species (ROS). Reactive oxygen species, such as free radicals and peroxides, represent a class of molecules that are derived from the metabolism of oxygen and exist in all aerobic organisms. ROS can attack many macromolecules in cell such as DNA, proteins and polyunsaturated lipids. They attack the cell membrane lipids causing their peroxidation and formation of lipid peroxidation products e.g., malondialdehyde, which interact with cellular proteins resulting in disturbed cellular function ${ }^{(\mathbf{1 0})}$. It is therefore crucial for thyrocytes to be efficiently protected against excessive ROS production; otherwise, it would not be possible for these cells to be kept alive and, obviously, to function properly. Thyrocytes have an effective mechanism to regulate antioxidative 
responses that counter the potential threat of oxidative stress. They include antioxidant enzymes such as superoxide dismutases, catalase, glutathione peroxidases, and peroxiredoxins ${ }^{(11)}$.

Much of the reactive oxygen species production occurs in mitochondria, via oxidative phosphorylation. Because the mitochondria contains specific receptors for the thyroid hormones, being one of the "favorite" target for them, the concept about a possible relationship between reactive oxygen species production and thyroid pathology has increasing importance (12). On the other hand, excess iodide, displays different effects depending on the intake amount and on the thyroid status at that time, leading to an increase or a decrease in thyroid hormones production ${ }^{(13)}$.

During severe iodine deficiency limitation of iodine could impair thyroid hormone (TH) synthesis and cause a compensatory increase in the cosubstrate $\mathrm{H}_{2} \mathrm{O}_{2}$ which in turn could extend ROS mediated DNA damage (14). On the other hand, it has been reported that the generation of $\mathrm{H}_{2} \mathrm{O}_{2}$ is inhibited by iodide in vivo and in vitro (5). Also, up to now, the mechanisms underlying the effect of iodine excess on thyroid function is poorly defined.

The aim of the current study was to investigate the effects of long term excessive iodine intake on gene expression of thyroidal sodium iodide symporter (NIS), D1 deiodinase and thyroid peroxidase (TPO), thyroid hormones, oxidative injury and antioxidative ability of euthyroid and hypothyroid Sprague Dawley rats.

\section{MATERIALS \& METHODS}

Animals

Ninety male Sprague Dawley rats weighing 220-240 g were used in the present study. They were purchased from Vaccine and Immunization Authority (Helwan, Cairo, Egypt) and housed (Animal House, Medical Physiology Department, Faculty of Medicine, Mansoura University, Egypt) in standard cages in groups of four to six animals per cage under controlled conditions (temperature $23 \pm 1{ }^{\circ} \mathrm{C}$, and a 12:12 light/dark cycle).The animals were fed ad libitum with standard rat chow and tap water. All experimental procedures of the present study were approved by the Medical Research Ethics Committee of Mansoura University, Egypt.

\section{Experimental protocol}

After 1-week acclimation to the laboratory environment animals were randomly assigned to four groups and given different doses of iodine at the levels of 3000 and $6000 \mu \mathrm{g} / \mathrm{l}$ by using sterile water as the vehicle.

- Group I: (15 rats): included normal (euthyroid) rats which received vehicle (tap water) daily for 4 weeks.

- Group II: (15 rats): included rats in which hypothyroidism was induced by administration of thiocyanate $(1 \mathrm{~g} / \mathrm{l})^{(15)}$ in the drinking water for 4 weeks.

- Group III: (30 rats): included normal (euthyroid) rats administered iodine in the drinking water in doses of 3000 $\mu \mathrm{g} / \mathrm{l}$ (IIIa, 15 rats) or $6000 \mu \mathrm{g} / \mathrm{L}$ (IIIb, 15 rats) ${ }^{(2)}$ for 4 weeks. 
- Group IV: (30 rats): included rats in which hypothyroidism was induced by administration of thiocyanate $(1 \mathrm{~g} / \mathrm{l})$ in the drinking water for 4 weeks, then they were administered iodine in the drinking water in doses of 3000 $\mu \mathrm{g} / \mathrm{l}$ (IVa, 15 rats) or $6000 \mu \mathrm{g} / 1$ (IVb, 15 rats) for another 4 weeks.

Sampling protocol:

Blood samples: At the end of experimental period, blood samples were obtained from the orbital sinus by using fine Pasteur pipette under halothane anesthesia. These blood samples were collected without anti coagulant, left for 10 minutes, then centrifuged for 10 minutes at 4000 rpm to obtain serum which was stored at $-20^{\circ} \mathrm{C}$ until analysis for determination of serum total thyroxine (tT4), total triiodothyronine (tT3) and thyrotropin (TSH).

Urine samples: At the end of experimental period, rats were housed in metabolic cages for 24 hours to collect urine samples for measurement of urinary iodine concentration.

Thyroid gland sampling: Thyroid glands were removed from all rats; 14 samples from each group were kept at $-80 \circ \mathrm{C}$ until biochemical analysis of oxidative markers (7 samples) and performing RT-PCR for gene expression (7 samples). Six samples were randomly selected from all groups for histological examination. They were placed in $10 \%$ buffered formalin, embedded in methacrylate, step sectioned, mounted on glass slides, and stained with hematoxylin and eosin.
Biochemical investigations:

Estimation of urinary iodine and plasma tT4, tT3 and TSH concentrations:

Iodine concentration in urine was measured by modified Cerarsenite colorimetric method $^{(\mathbf{1 6})}$. Total thyroxine $\left(\mathrm{tT}_{4}\right)$ and total triiodothyronine $\left(\mathrm{tT}_{3}\right)$ were measured in rat serum using ELISA Kits (GenWay Biotech Inc., San Diego, USA Cat No. 40-101-325036, and 40101-325038 respectively), which employs a quantitative enzyme immunoassay technique. The measurement protocol was done according to the manufacturer's instruction, absorbance was read at $450 \mathrm{~nm}$ wave length using plate reader (Tecan, SunRise Absorbance reader). Moreover, thyrotropin (TSH) was measured in rat serum using EILSA Kit (Shibayagi Co., Japan, Product Code \# AKRTS-010), which employs a quantitative immunoenzymometric assay technique. The measurement protocol was done according to the manufacturer's instruction; absorbance was read at $450 \mathrm{~nm}$ using plate reader (Tecan, SunRise Absorbance reader).

Estimation of thyroid oxidative and antioxidative parameters:

Thyroid glands were removed from all rats; they were weighed and kept at $-20{ }^{\circ} \mathrm{C}$ until biochemical analysis.

Tissue Homogenate preparation: Thyroid tissue was perfused with a PBS (phosphate buffered saline) solution, pH 7.4 containing $0.16 \mathrm{mg} /$ $\mathrm{ml}$ heparin to remove any red blood cells and clots. Then, thyroid was homogenized in $5-10 \mathrm{ml}$ cold buffer (i.e. $50 \mathrm{mM}$ potassium phosphate, $\mathrm{pH}$ 
7.5. $1 \mathrm{mM}$ EDTA). Homogenates were centrifuged at $10000 \times \mathrm{g}$ for 15 minutes at $4^{\circ} \mathrm{C}$ and the supernatant was kept at $-80 \circ \mathrm{C}$ till used for analysis of lipid peroxides, total antioxidants, catalase, superoxide dismutase and Glutathione Stransferases.

$$
\text { Lipid }
$$

peroxides

(malondialdehyde, MDA) were analyzed by the method of Buege and Aust ${ }^{(17)}$ using colorimetric kit (BioDiagnostics, Dokki, Giza, Egypt, Cat. No. \# MD 2528). Total antioxidants were colorimetrically determined according to the method described by Koracevic et al. (18), using the kit (Cat. No. \# TA 25 12) supplied by Bio-Diagnostics, Dokki, Giza, Egypt. Catalase was estimated by the method described by Aebi ${ }^{(19)}$ using colorimetric kit (Bio-Diagnostics, Dokki, Giza, Egypt, Cat. No. \# CA 25 16). Superoxide dismutase was determined according to the method described by Nishikimi ${ }^{(20)}$ using the colorimetric kit (Bio-Diagnostics, Dokki, Giza, Egypt, Cat. No. \# SD 25 20). Glutathione S- transferases (GST) was determined by UV method as described by Habig and Jakoby (21) using the kit (Cat. No. \# GT 25 18) provided by Bio-Diagnostics, Dokki, Giza, Egypt. The concentrations of nitric oxide (NO) were measured through the determination of nitrite and nitrate levels with the QuantiChrom $^{\text {TM }}$ Nitric Oxide Assay Kit (DINO-250) (BioAssay Systems, USA), which is designed to accurately measure NO production following reduction of nitrate to nitrite using improved Griess method ${ }^{(22) .}$
Semiquantitative

Reverse transcriptase-PCR Total RNA extraction from the thyroid of rats:

Total RNA was extracted from thyroid tissue, the thyroid gland was shock freezed by liquid nitrogen and used immediately for RNA extraction using TriFast TM reagent (PeqLab. Biotechnologie $\mathrm{GmbH}$, Carl-Thiersch St. 2B 91052 Erlongen, Germany, Cat. No. 30-2010) according to the manufacturer's instructions. The remaining DNA was removed by digestion with DNase I (Sigma). The concentration of isolated RNA was determined spectrophotometrically by measuring the optical density (OD) at 260 nm (JenWay, Genova Model, UK). $10 \mu 1$ of each sample was added to $990 \mu \mathrm{l}$ of DEPC treated water and quantified by measuring the absorbance at $260 \mathrm{~nm}$ as RNA yield $(\mu \mathrm{g} / \mathrm{ml})=\mathrm{A} 260 \times 40 \times 100$ (dilution factor) (23). The purity of RNA was determined by gel electrophoresis through formaldehyde agarose gel electrophoresis and ethidium bromide staining to show 2 sharp purified bands, these two bands represented $28 \mathrm{~S}$ and $18 \mathrm{~S}$ ribosomal RNA.

\section{RT-PCR for extracted RNA:}

RT-PCR was performed using Ready-to-Go RT-PCR beads for first cDNA synthesis and PCR reaction provided by Amersham Biosciences, England. Cat. No. 27-9266-01, according to the method of Berchtold $^{(24) .}$

Ready-to-Go RT-PCR beads utilize Moloney Murine leukemia virus (M-MuLV) reverse transcriptase and Taq polymerase to generate PCR product from RNA template. Each bead is optimized to allow the first 
strand cDNA synthesis and PCR reaction to proceed sequentially as a single tube, single step reaction. The reaction passed as follow:

\section{A) Synthesis of cDNA:}

The followings were added to each tube containing the beads: $2 \mu 1$ of first strand primer, provided by the kit, $3 \mu \mathrm{l}$ containing $30 \mathrm{pmol}$ of PCR gene-specific primer (sense), $3 \mu \mathrm{l}$ containing 30 pmol of PCR genespecific primer (anti-sense), $25 \mu \mathrm{l}$ of total template RNA containing $1 \mathrm{ug}$ and $17 \mu \mathrm{l}$ of DEPC-treated water to obtain a total volume of $50 \mu \mathrm{l}$. One tube was prepared as a negative control reaction to test for DNA contamination.
The dehydrated bead (without template and primers) was incubated at $95^{\circ} \mathrm{C}$ for 10 minutes to inactivate the M-MuLV reverse transcriptase. 50 ul mineral oil were added to overlay the reaction. The reactions were transferred to the thermal cycler and incubated at $40^{\circ} \mathrm{C}$ for 30 minutes for synthesis of cDNA followed by incubation at $95^{\circ} \mathrm{C}$ for 5 minutes to inactivate the reverse transcriptase and completely denature the template.

Gene specific primers used were:

Gene specific primers were purchased from Biolegio. BV, PO Box 91, 5600 AB Nijmegen, Netherlands.

\begin{tabular}{|c|c|c|}
\hline Gene & Primer & Reference \\
\hline NIS & 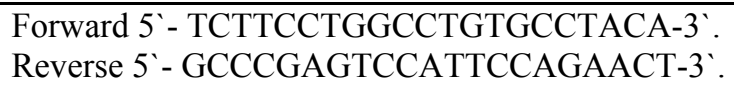 & (25) \\
\hline $\begin{array}{l}\text { Type } 1 \text { deiodinase } \\
\text { (D1) }\end{array}$ & $\begin{array}{l}\text { Forward 5`- GACAGGGCTGAGTATGGG-3`. } \\
\text { Reverse 5`-GCTCGGTATTGCTTTATCT-3`. }\end{array}$ & (26) \\
\hline TPO & $\begin{array}{l}\text { Forward 5 - GCACCTTGGATCTGGCATCAC-3'. } \\
\text { Reverse 5 - TGTGGGAAGGTCTCCCTCCAT-3`. }\end{array}$ & (25) \\
\hline $\begin{array}{l}\text { Internal house } \\
\text { keeping (control) } \\
\text { gene (GAPDH) }\end{array}$ & $\begin{array}{l}\text { Forward } 5{ }^{`} \text { - CCATCACCATCTTCCAGGAG-3`. } \\
\text { Reverse } 5{ }^{\prime} \text { - CCTGCTTCACCACCTTCTTG-3`. }\end{array}$ & (25) \\
\hline
\end{tabular}




\section{B) Amplification of cDNA by PCR:}

Thermal cycling reaction was performed using thermal cycler (Minicycler PTC150 with the following program:

\begin{tabular}{|c|c|c|c|c|}
\hline & NIS & $\overline{D I}$ & TPO & $\begin{array}{l}\text { GAPDH(internal } \\
\text { control-House } \\
\text { keeping gene) }\end{array}$ \\
\hline $\begin{array}{l}\text { Initial } \\
\text { denaturation }\end{array}$ & $\begin{array}{l}94 \circ \mathrm{C} \text { for } 5 \\
\text { minutes }\end{array}$ & $\begin{array}{l}95^{\circ} \mathrm{C} \text { for } 3 \\
\text { minutes }\end{array}$ & $\begin{array}{l}94^{\circ} \mathrm{C} \text { for } 5 \\
\text { minutes }\end{array}$ & $94 \circ \mathrm{C}$ for 5 minutes \\
\hline \multicolumn{5}{|l|}{ Cycles } \\
\hline Number & 30 & 30 & 30 & 25 \\
\hline -denaturation & $\begin{array}{l}94{ }^{\circ} \mathrm{C} \text { for } 1 \\
\text { minute }\end{array}$ & $\begin{array}{l}94{ }^{\circ} \mathrm{C} \text { for } 30 \\
\text { seconds }\end{array}$ & $\begin{array}{l}94{ }^{\circ} \mathrm{C} \text { for } 1 \\
\text { minute }\end{array}$ & $94{ }^{\circ} \mathrm{C}$ for 1 minute \\
\hline $\begin{array}{l}\text {-primer } \\
\text { annealing }\end{array}$ & $\begin{array}{l}55^{\circ} \mathrm{C} \text { for } 1 \\
\text { minute }\end{array}$ & $\begin{array}{l}52 \circ \mathrm{C} \text { for } 30 \\
\text { seconds }\end{array}$ & $\begin{array}{l}55^{\circ} \mathrm{C} \text { for } 1 \\
\text { minute }\end{array}$ & $55^{\circ} \mathrm{C}$ for 1 minute \\
\hline -Extension & $\begin{array}{l}72 \circ \mathrm{C} \text { for } 1 \\
\text { minute }\end{array}$ & $\begin{array}{l}72 \circ \mathrm{C} \text { for } 1 \\
\text { minute }\end{array}$ & $\begin{array}{l}72 \circ \mathrm{C} \text { for } 1 \\
\text { minute }\end{array}$ & $72 \circ \mathrm{C}$ for 1 minute \\
\hline $\begin{array}{l}\text { Final } \\
\text { extension }\end{array}$ & $\begin{array}{l}72 \circ \mathrm{C} \text { for } 7 \\
\text { minutes }\end{array}$ & $\begin{array}{l}72 \circ \mathrm{C} \text { for } 3 \\
\text { minutes }\end{array}$ & $\begin{array}{l}72 \circ \mathrm{C} \text { for } 7 \\
\text { minutes }\end{array}$ & $72 \circ \mathrm{C}$ for 7 minutes \\
\hline Product size & $506 \mathrm{bp}$ & 722 bp & $502 \mathrm{bp}$ & $577 \mathrm{bp}$ \\
\hline
\end{tabular}

\section{C) Detection of amplified RT-PCR} products:

For semiquantitative RT-PCR, the products of amplification were subjected to agarose gel electrophoresis using 2\% agarose stained with ethidium bromide and visualized via light UV Transilluminator (Model TUV-20, OWI. Scientific, Inc. 800 242-5560) and photographed under fixed conditions (the distance, the light and the zoom).

The results photos were analyzed with scion image ${ }^{\circledR}$ release Alpha 4.0.3.2. software for windows $\AA$ which performs bands detection and conversion to peaks. Area under each peak were calculated in square pixels and used for quantification. Gene expression levels were determined by calculating the ratio between the square pixel value of the target gene in relation to the internal house keeping control gene (GAPDH).

Negative control tubes showed no PCR products indicating that all reagents were free from target sequence contamination.

\section{Statistical analysis:}

The data were expressed as mean \pm standard deviation of mean (Mean \pm SDM). Data were processed and analyzed using the Statistical Package of Social Science version 10.0 (SPSS, version 10.0). One way ANOVA was done followed by Tukey's post hoc test. A minimum level of significance is considered if $\mathrm{P}$ is $\leq 0.05$. 
Table (1):

\section{RESULTS}

\begin{tabular}{|c|c|c|c|c|c|c|}
\hline & \multirow{2}{*}{$\begin{array}{l}\text { Normal } \\
\text { (Euthyroid) } \\
\text { rats }\end{array}$} & \multirow[t]{2}{*}{$\begin{array}{l}\text { Hypothyroid } \\
\text { rats }\end{array}$} & \multicolumn{2}{|c|}{$\begin{array}{l}\text { Euthyroid rats administered } \\
\text { iodine }\end{array}$} & \multicolumn{2}{|c|}{$\begin{array}{l}\text { Hypothyroid rats administered } \\
\text { iodine }\end{array}$} \\
\hline & & & $\begin{array}{l}\text { Iodine } \\
(3000 \mu \mathrm{g} / \mathrm{L})\end{array}$ & $\begin{array}{l}\text { Iodine } \\
(6000 \mu \mathrm{g} / \mathrm{L})\end{array}$ & $\begin{array}{l}\text { Iodine } \\
(3000 \mu \mathrm{g} / \mathrm{L})\end{array}$ & $\begin{array}{l}\text { Iodine } \\
(6000 \mu \mathrm{g} / \mathrm{L})\end{array}$ \\
\hline TSH (ng/ml) & $4.71 \pm 0.61$ & $6.71 \pm 0.52^{\mathrm{a}}$ & $4.81 \pm 0.63^{b}$ & $4.92 \pm 0.72^{\mathrm{b}}$ & $4.61 \pm 0.66^{b}$ & $4.52 \pm 0.58^{b}$ \\
\hline$T_{4}(\mathrm{ug} / \mathrm{dl})$ & $3.87 \pm 0.31$ & $2.01 \pm 0.17^{\mathrm{a}}$ & $8.57 \pm 0.56^{\text {ab }}$ & $9.48 \pm 0.59^{\text {ab }}$ & $3.41 \pm 0.34^{\text {bc }}$ & $3.52 \pm 0.36^{\mathrm{bc}}$ \\
\hline$T_{3}(\mathrm{ng} / \mathrm{ml})$ & $1.32 \pm 0.05$ & $0.87 \pm 0.04^{\mathrm{a}}$ & $1.11 \pm 0.05^{\text {ab }}$ & $1.08 \pm 0.09^{\text {ab }}$ & $1.14 \pm 0.04^{\text {ab }}$ & $1.17 \pm 0.03^{\text {ab }}$ \\
\hline T3/T4 ratio & $0.34 \pm 0.09$ & $0.44 \pm 0.11^{\mathrm{a}}$ & $0.13 \pm 0.03^{\text {ab }}$ & $0.11 \pm 0.05^{\text {ab }}$ & $0.33 \pm 0.07^{\mathbf{b c}}$ & $0.33 \pm 0.09^{b \mathbf{c}}$ \\
\hline Urinary iodine level( $\mu \mathrm{g} / 24$ hours $)$ & $44.01 \pm 4.12$ & $53.01 \pm 3.22^{\mathrm{a}}$ & $65.61 \pm 5.21^{\mathrm{ab}}$ & $72.78 \pm 5.62^{\mathrm{ab}}$ & $61.11 \pm 3.36^{\mathrm{ab}}$ & $67.15 \pm 4.54^{\text {ab }}$ \\
\hline Thyroid gland weight (mg) & $14.4 \pm 0.7$ & $24.88 \pm 0.9^{\mathrm{a}}$ & $15.6 \pm 1.1^{\mathrm{b}}$ & $15.9 \pm 1.2^{b}$ & $18.6 \pm 0.8^{\text {ab }}$ & $19.2 \pm 0.9^{\text {ab }}$ \\
\hline Total antioxidants $(\mathrm{mmol} / \mathrm{L})$ & $0.237 \pm 0.032$ & $0.645 \pm 0.035^{\mathrm{a}}$ & $0.855 \pm 0.079^{\mathrm{a}}$ & $1.243 \pm 0.036^{\mathrm{a} *}$ & $1.41 \pm 0.084^{\mathrm{abc}}$ & $1.85 \pm 0.058^{\mathrm{abc} *}$ \\
\hline GST(U/g tissue) & $225.44 \pm 77.88$ & $415.44 \pm 87.89^{\mathrm{a}}$ & $683.11 \pm 141.52^{a}$ & $716.77 \pm 92.23^{\mathrm{a}}$ & $699.74 \pm 77.17^{\text {ab }}$ & $748.63 \pm 93.69^{\text {ab }}$ \\
\hline CAT(U/g tissue) & $0.16 \pm 0.032$ & $0.35 \pm 0.032^{\mathrm{a}}$ & $0.45 \pm 0.06^{\mathrm{a}}$ & $0.49 \pm 0.06^{\mathrm{a}}$ & $0.49 \pm 0.03^{b}$ & $0.51 \pm 0.04^{b}$ \\
\hline SOD(U/g tissue) & $35.06 \pm 4.33$ & $53.06 \pm 5.31^{\mathrm{a}}$ & $61.64 \pm 8.87^{\mathrm{a}}$ & $64.43 \pm 6.55^{a}$ & $70.32 \pm 8.48^{6}$ & $73.93 \pm 5.07^{b}$ \\
\hline $\mathrm{NO}(\mu \mathrm{mol} / \mathrm{L})$ & $3.07 \pm 1.35$ & $5.37 \pm 1.15^{\mathrm{a}}$ & $7.85 \pm 0.89^{\mathrm{a}}$ & $8.37 \pm 0.49^{\mathrm{a}}$ & $7.91 \pm 0.67^{b}$ & $8.11 \pm 0.51^{b}$ \\
\hline MDA(nmol/g tissue) & $1.25 \pm 0.26$ & $5.43 \pm 0.76^{\mathrm{a}}$ & $3.31 \pm 0.46^{\mathrm{a}}$ & $6.72 \pm 0.74^{\mathrm{a} *}$ & $9.7 \pm 0.44^{\text {abc }}$ & $15.54 \pm 0.97^{\text {abc } *}$ \\
\hline NIS/GAPDH mRNA & $1.3 \pm 0.1$ & $3.84 \pm 0.5^{\mathrm{a}}$ & $0.7 \pm 0.08^{\text {ab }}$ & $0.4 \pm 0.03^{\mathrm{ab}} *$ & $2.5 \pm 0.2^{\mathrm{ab}}$ & $1.9 \pm 0.1^{\mathrm{ab}} *$ \\
\hline D1/GAPDH mRNA & $1.25 \pm 0.1$ & $1.58 \pm 0.1^{\mathrm{a}}$ & $0.87 \pm 0.06^{\text {ab }}$ & $0.85 \pm 0.08^{\text {ab }}$ & $1.33 \pm 0.2^{\mathrm{b}}$ & $1.39 \pm 0.2^{\mathrm{b}}$ \\
\hline TPO/GAPDH mRNA & $1.3 \pm 0.1$ & $2.8 \pm 0.2^{\mathrm{a}}$ & $1.4 \pm .0 .2^{\mathrm{b}}$ & $1.5 \pm 0.2^{\mathrm{b}}$ & $2.2 \pm 0.1^{\text {ab }}$ & $1.9 \pm 0.1^{\text {ab }}$ \\
\hline
\end{tabular}

a: significant $(p<0.05)$ relative to normal euthyroid rats. b: significant $(p<0.05)$ relative to hypothyroid rats. $c$ : $\operatorname{significant}(\mathrm{p}<0.05)$ relative to the corresponding euthyroid rats group administered iodine. ${ }^{*}$ : significant $(\mathrm{p}<0.05)$ relative to the corresponding group administered iodine (3000 ug/L). TSH: throid stimulating hormone, T4: thyroxine, T3: triiodothyronine, GSH: glutathione, CAT: catalase, SOD: superoxide dismutase, NO: nitric oxide, MDA: malondialdehyde, NIS: sodium iodide transporter, TPO: thyroid peroxidase. 
The concentration of iodine in urine is currently the most widely used as biochemical marker of iodine intake. Urinary iodine concentration increased in rats after thiocyanate induced hypothyroidism. Moreover, after exposure to high doses of iodine $(3000$ or $6000 \mu \mathrm{g} / \mathrm{l})$ for 4 weeks, urinary iodine concentration of rats increased in a dose-dependent manner $(\mathrm{p}<0.05)$.

Plasma levels of thyroxine $\left(\mathrm{T}_{4}\right)$ and triiodothyronine $\left(\mathrm{T}_{3}\right)$ were decreased significantly in hypothyroid rats $(p<0.05)$. Compared to control group, serum $\mathrm{T}_{4}$ level increased while serum T3 level decreased significantly in groups III \& IV of euthyroid rats. Moreover, excessive administration of iodine $(3000$ or $6000 \mu \mathrm{g} / \mathrm{l})$ to hypothyroid rats caused significant increase in plasma $T_{4}$ and $T_{3}$ levels $(p<0.05)$ relative to hypothyroid rats, plasma $\mathrm{T}_{4}$ reached nearly the normal level $(p>0.05)$ but $T_{3}$ is still below normal $(\mathrm{p}<0.05)$.

Plasma TSH level was significantly increased in hypothyroid rats but it decreased significantly $(p<0.05)$ with excessive iodine administration (3000 or $6000 \mu \mathrm{g} / \mathrm{l})$ and reach nearly the normal level ( $p>0.05)$. Compared to control group, plasma TSH was non significantly changed with high iodine doses (3000 or $6000 \mu \mathrm{g} / \mathrm{l})$. Thyroid gland weight was significantly $(p<0.05)$ increased in rats with thiocyanate induced hypothyroidism, however, after excess iodine $(3000$ or $6000 \mu \mathrm{g} / \mathrm{l})$ administration, its weight was significantly decreased $(\mathrm{p}<0.05)$ but still more than that of control group $(p<0.05)$. On the other hand, the gland weight showed non significant increase in euthyroid rats with excess iodine $(\mathrm{p}>0.05)$.

In the thyroid gland of rats with thiocyanate induced hypothyroidism, a significant increase $(p<0.05)$ in lipid peroxides (MDA) concentration was observed relative to that of the control group. Furthermore, in euthyroid or hypothyroid rats, a high iodine dose was associated with a significant increase $\quad(p<0.05)$ in MDA concentrations. There was a significant increase $(\mathrm{p}<0.05)$ in glutathione $\mathrm{S}$ transferase (GST), catalase, superoxide dismutase (SOD), nitric oxide (NO), and total antioxidants of thyroid gland in rats with thiocyanate induced hypothyroidism and in euthyroid or hypothyroid rats given high doses of iodine (3000 or $6000 \mu \mathrm{g} / \mathrm{l})$

Gene expression of NIS increased significantly $(\mathrm{p}<0.05)$ in rats with thiocyanate induced hypothyroidism, meanwhile, it decreased $(\mathrm{p}<0.05)$ after high iodine doses $(3000$ or $6000 \mu \mathrm{g} / \mathrm{l})$ but it remains higher than that of the control group $(p<0.05)($ Fig. 1$)$. On the other hand, despite the significant increase in deiodinase gene expression in thiocyanate induced hypothyroid rats, it significantly $(\mathrm{p}<0.05)$ decreased after excess iodine intake either to eu- or hpyothyroid rats $(p<0.05)$ (Fig.2). Gene expression of thyroid peroxidase (TPO) increased significantly $(\mathrm{p}<0.05)$ in hypothyroid rats but it decreased after high iodine administration $(\mathrm{p}<0.05)$ although it remains more than that of the control group $(\mathrm{p}<0.05)$. In euthyroid rats no significant change in TPO gene expression was reported after excess iodine intake(Fig.3). 
Moreover, the morphological and biochemical perturbations were confirmed by the histological study of thyroid glands. Indeed, thyroids of thiocyanate treated rats presented closed follicles, follicular cell hyperplasia, an increase in follicular number and vascularity as well as a decrease in colloid volume. However, in control rats, the majority of follicles were larger than those in thiocyanate treated rats, lined by more flattened epithelium and filled with a deeper staining colloid (Fig. 5). Unlike the histological appearance of normal thyroids, an obvious colloid goiter was also induced in the thyroid of rats exposed to high doses of iodine; the follicles were filled with colloid and the epithelial cells were flattened (Fig. 6). The histological aspect of the thyroid glands, after excessive iodine intake in rats exposed to thiocyanate induced hypothyroidism, was improved comparatively to animals of group 2, with an increase in colloid volume and a decrease of follicular cell hypertrophy.

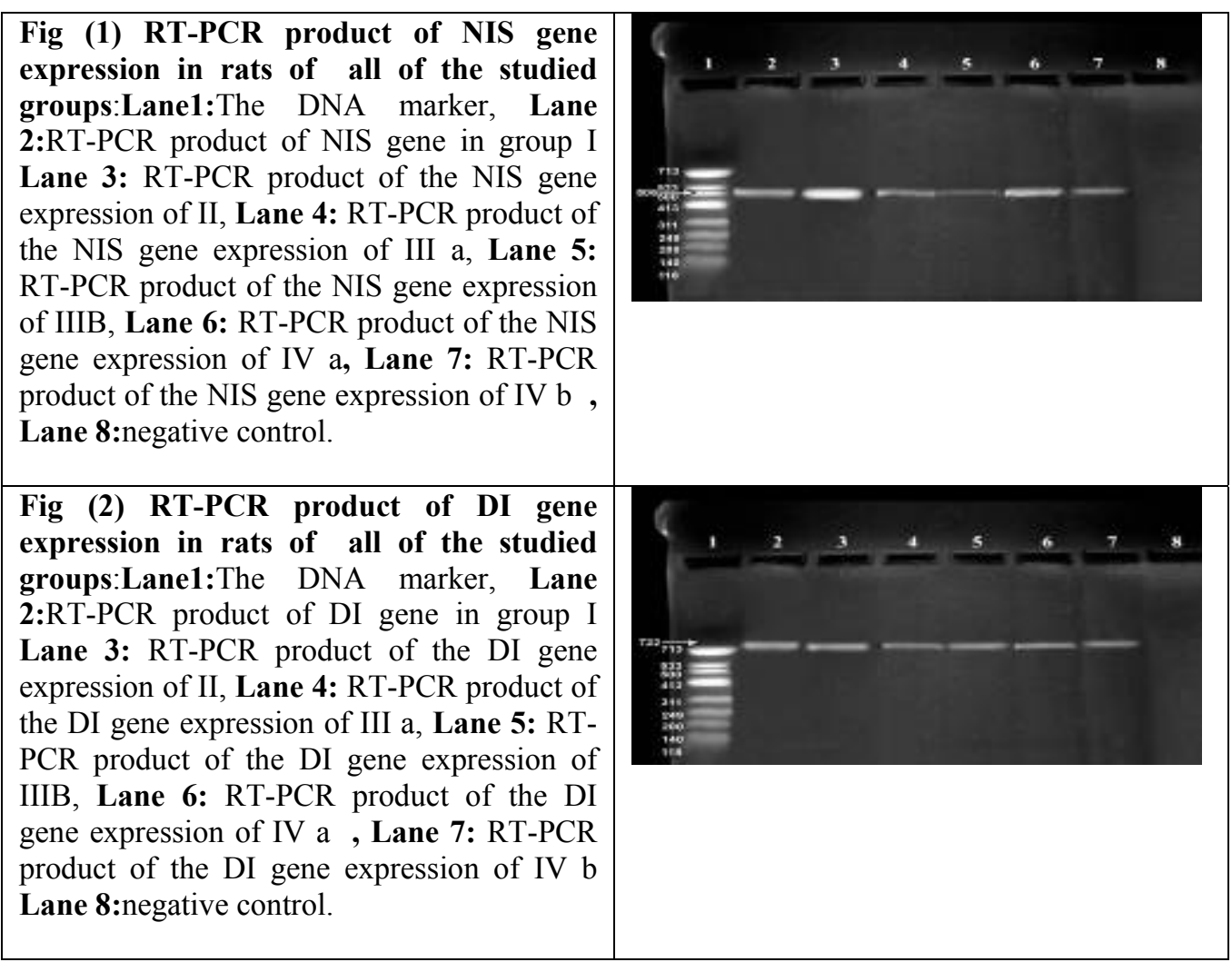




\begin{tabular}{|c|c|}
\hline $\begin{array}{l}\text { Fig (3) RT-PCR product of TPO gene } \\
\text { expression in rats of all of the studied } \\
\text { groups:Lane1:The DNA marker, Lane } \\
\text { 2:RT-PCR product of TPO gene in group I } \\
\text { Lane 3: RT-PCR product of the TPO gene } \\
\text { expression of II, Lane 4: RT-PCR product of } \\
\text { the TPO gene expression of III a, Lane 5: } \\
\text { RT-PCR product of the TPO gene expression } \\
\text { of IIIB, Lane 6: RT-PCR product of the TPO } \\
\text { gene expression of IV a , Lane 7: RT-PCR } \\
\text { product of the TPO gene expression of IV b } \\
\text { Lane 8:negative control. }\end{array}$ & $\begin{array}{l}12345678 \\
\equiv-1-1-1\end{array}$ \\
\hline $\begin{array}{l}\text { Fig (4) RT-PCR product of GAPDH } \\
\text { (internal control-housekeeping gene) } \\
\text { gene expression in rats of all of the } \\
\text { studied groups:Lane1:The DNA marker, } \\
\text { Lane 2:RT-PCR product of GAPDH gene in } \\
\text { group I Lane 3: RT-PCR product of the } \\
\text { GAPDH gene expression of II, Lane 4: RT- } \\
\text { PCR product of the GAPDH gene expression } \\
\text { of III a, Lane 5: RT-PCR product of the } \\
\text { GAPDH gene expression of IIIB, Lane 6: } \\
\text { RT-PCR product of the GAPDH gene } \\
\text { expression of IV a , Lane 7: RT-PCR } \\
\text { product of the GAPDH gene expression of } \\
\text { IV b, Lane 8:negative control. }\end{array}$ & 123.5 .67 \\
\hline
\end{tabular}




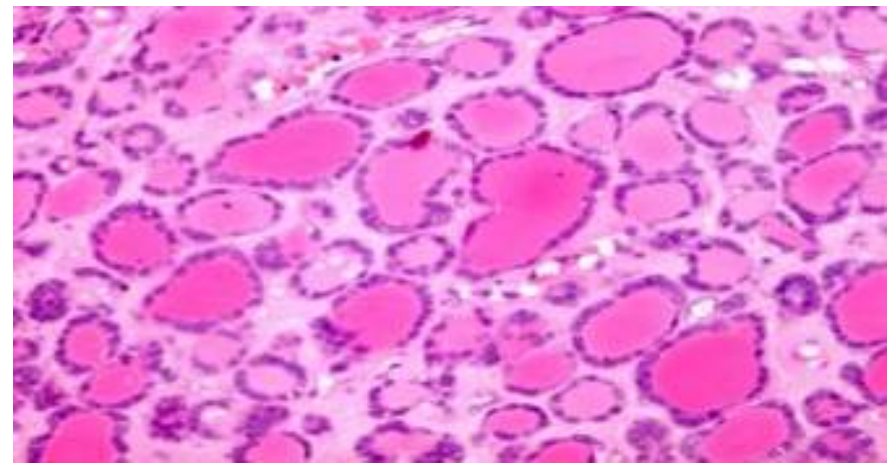

Figure (5): Normal thyroid tissue showing small thyroid follicles lined by cuboidal cells and contained intraluminal colloid (Hx \&E X100).

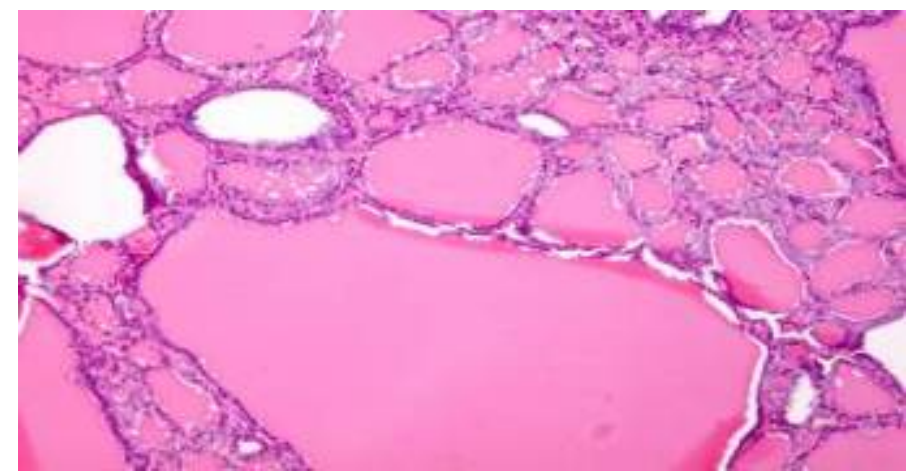

Figure (6): Colloid goiter showing variably sized thyroid follicle lined by flattened cells and distended by colloid (Hx \&E X100).

\section{DISCUSSION}

Iodine excess can be defined as the amount of iodide beyond the physiological requirement for adequate thyroid hormone synthesis $^{(27) . ~ F o r ~ m o s t ~ a d u l t s, ~} 150 \mu \mathrm{g}$ iodine is daily required for thyroid hormone synthesis and up to $200 \mu \mathrm{g}$ per day for pregnant women. Zhao et al. ${ }^{(28)}$ suggested that maximum allowable iodine concentrations may be set at $800 \mu \mathrm{g} / \mathrm{L}$ in the urine of adults or $300 \mu \mathrm{g} / \mathrm{l}$ in drinking water if
$5 \%$ goiter prevalence is defined as a public health problem. Under certain conditions, the consumption of iodine may be much higher. Generally, thyroid dysfunction was found to occur when iodine was administered at levels 10 times the physiologic requirement; however, effect of excess iodine on thyroid function varies in different species ${ }^{(29)}$.

In the present study, we aimed to investigate the effects of chronic excessive iodine intake on gene expression of thyroidal sodium iodide 
symporter (NIS), D1 deiodinase and thyroid peroxidase (TPO), thyroid hormones, oxidative injury and antioxidative ability of euthyroid and hypothyroid Sprague Dawley rats. These rats were exposed to 3000 and $6000 \mu \mathrm{g} / \mathrm{l}$ iodine in drinking water for 4 weeks, which corresponded to $10-$ and 20 - fold of the adequate iodine intake for rats ${ }^{(2)}$.

In the current study, thiocyanate treatment of group II rats provoked an increase in urinary iodine concentration, a decrease in $T_{3}$ and $T_{4}$ and an increase in TSH plasma levels. Moreover, gene expression of NIS, D1 deiodinase and TPO were significantly increased. Though $\mathrm{T}_{4}$ and $T_{3}$ are significantly lower in thiocyanate induced hypothyroid rats than control group, the $T_{3} / T_{4}$ ratio in the hypothyroid group was higher. This can be explained by the significant increase in D1 deiodinase gene expression that helps to convert more $T_{4}$ to $T_{3}$. The shift to increase $T_{3}$ secretion may be very important for the adaptation to iodine deficiency because $T_{3}$ possesses about four times the metabolic potency of $\mathrm{T}_{4}$ but requires only $75 \%$ as much iodine for synthesis ${ }^{(30)}$. Our results were in agreement with those of Wang et al. ${ }^{(26)}$ who demonstrated that in rats with deficient iodine intake, D1 deiodinase activity increased relative to normal rats. Because the iodine is the precursor of thyroid hormones biosynthesis, the transport and the concentration of iodine within the thyroid gland represents the first step in the production of the iodine content of thyroid hormones ${ }^{(31)}$. Indeed, iodide uptake occurs across the basolateral membrane of polarized thyroid follicular cells and is an active transport driven by inwardly directed $\mathrm{Na}+$ gradient ${ }^{(32)}$. In rats, the activity of sodium iodide symporter (NIS), an intrinsic membrane-associated protein cloned and characterized, was shown to be under the control of TSH ${ }^{(33)}$. Thiocyanate and iodide $\left(\mathrm{I}^{-}\right)$have a similar charge and a comparable ionic volume, and the $\mathrm{SCN}^{-}$could be transported by the NIS system ${ }^{(34)}$. Thus, the most well-characterized effect of thiocyanate on iodine utilization is competitive inhibition of the sodium iodide symporter (NIS), although inhibition of iodide organification may also take place ${ }^{(35)}$. Furthermore, similarly to iodide trapping, the $\mathrm{SCN}^{-}$catch by the thyroid cell is increased in the presence of the $\mathrm{TSH}^{(36)}$ and the intrathyroidal metabolism of $\mathrm{SCN}^{-}$ also increased after TSH stimulation. Hence, the $\mathrm{SCN}^{-}$would be rapidly oxidized by the thyroperoxidase (TPO) enzyme in the presence of $\mathrm{H}_{2} \mathrm{O}_{2}$. Therefore, as it was recently demonstrated by Contempré et al. (37), the $\mathrm{SCN}^{-}$is not accumulated in the thyrocyte, and it ultimately generates an I-deficient thyroid with a decrease in thyroid hormones' synthesis. Maier et al. ${ }^{(14)}$ suggested that the thyroid response to iodine deficiency is not only restricted to enlargement, but also very likely involves cellular hyperfunction, as suggested by increased mRNA expression of the TSHR, TPO and sodium-iodine symporter.

Administration of excess iodine, in doses of 3000 and $6000 \mu \mathrm{g} / \mathrm{l}$, to euthyroid rats caused significant increase in $T_{4}$ and decrease in $T_{3}$ plasma levels as compared to normal 
rats whilst non significant change in serum TSH was reported. These results were in accord with those of Yang et al. ${ }^{(2)}$ who reported that, serum $T_{4}$ level increased and serum $T_{3}$ level decreased significantly in mice, as compared to control group, when iodine dose reached $3000 \mu \mathrm{g} / \mathrm{l}$, whereas, when the dose was $1500 \mu \mathrm{g} / \mathrm{l}$ iodine had no obvious effect. This change may be mainly related to the inhibition of D1-deiodinase activity, resulting in a decrease in the generation of $\mathrm{T}_{3}$ from $\mathrm{T}_{4}{ }^{(26)}$. This is obvious in the present results which demonstrated significant decrease in 5'-deiodinase gene expression. This may be taken as an effective way to protect organism from injury caused by too much $\mathrm{T}_{3}{ }^{(26)}$. Also, in euthyroid rats, high iodine doses resulted in significant decrease in NIS and D1 deiodinase genes expression but TPO was non significantly changed. Excess iodide displays different effects depending on the intake amount and on the thyroid status at that time ${ }^{(\mathbf{1 3}) .}$ The physiologic requirement in adult is about $150-200 \mu \mathrm{g}$ daily. In the acute inhibitory response (the wellknown Wolff-Chaikoff effect), inhibition of its own organification and subsequent thyroid hormone synthesis and acute inhibition of hormone release from the thyroid is the fundamental phenomenon. Iodide oxidation requires thyroperoxidase and hydrogen peroxide generation that is stimulated by thyrotropin through calcium-phosphatidylinositol cascade. Recent studies suggest that excess iodide inhibits calcium-phosphatidylinositol cascade and hydrogen peroxide production does not occur ${ }^{\mathbf{3 8})}$. Recent findings proposed that iodopeptides are formed that temporarily inhibit thyroid peroxidase (TPO) mRNA and protein synthesis and, therefore, thyroglobulin iodination. The Wolff-Chaikoff effect is an effective mean of rejecting the large quantities of iodide and therefore preventing the thyroid from synthesizing large quantities of thyroid hormones. On the other hand, the acute inhibitory Wolff-Chaikoff effect is temporary, lasts for a few days, and then, through the so-called "escapes" phenomenon, the organification of intrathyroidal iodide resumes and the synthesis of thyroxin and triiodothyronine returns, despite continuous iodide administration. This is achieved by decreasing the intrathyroidal inorganic iodine concentration by down regulation of the sodium iodine symporter (NIS) and therefore permits the TPO- $\mathrm{H}_{2} \mathrm{O}_{2}$ system to resume its activity ${ }^{(39)}$. This impressive drop in the NIS activity occurs by a TSH-independent autoregulation which appears to operate at the transcriptional and/or post-transcriptional level ${ }^{(\mathbf{4 0 )}}$. This is apparent in our results which demonstrated a decrease in NIS gene expression and non significant change in TPO gene expression as compared with normal.

Moreover, the present results showed that high iodine intake in hypothyroid rats increase plasma $\mathrm{T}_{4}$ level nearly to normal level whereas $\mathrm{T}_{3}$ increase but still below normal. Our results were in agreement with those of Ghorbel et al. (15). Furthermore, NIS and TPO genes expression were significantly increased in hypothyroid rats administered excess iodine relative to 
normal but decreased relative to thiocyanate induced hypothyroid rats, which increased synthesis and secretion of $T_{3}$ and $T_{4}$ while D1 deiodinase was non significantly changed. The non significant change in D1 deiodinase with normal $T_{3} / T_{4}$ ratio may be considered as an effective mean to protect organism from injury caused by too much $\mathrm{T}_{3}{ }^{(26) \text {. }}$

Rats treated with thiocyanate (group II) showed an increase in thyroid gland weights was obtained. Our results were in accord with those of Ghorbel et al. ${ }^{(15)}$ This result can be explained by a feedback to the hypothalamo-hypophysis axis, indicating the low levels of $\mathrm{T}_{4}$ and $\mathrm{T}_{3}$ in the blood; hence, more thyroidstimulating hormone (TSH) was released in order to increase the production of these hormones. Consequently, hypothyroidism and hypertrophy of the thyroid gland were evidenced. Some studies showed that hypothyroidism is associated with modest pituitary enlargement in humans, and several case reports of pituitary enlargement sufficient to present visual impairment through comparison of the optic chiasma have been published ${ }^{(41)}$. These data correlate with an important TSH secretion under hypothyroid state, as it was found in our study. On the other hand, excess iodine intake in euthyroid rats caused non significant change in thyroid gland weight whereas in hypothyroid rats the weight decreased relative to that of hypothyroid rats but still higher than normal.

Histological changes observed in thyroid slides of group II were characterized by closed follicles, follicular cell hyperplasia, an increase in follicular number, and vascularity, as well as a decrease in colloid volume. These data confirmed previous results by Ghorbel et al. ${ }^{(15)}$. Moreover, our results were in accord with Soussia and collaborators. ${ }^{(42)}$ who had demonstrated that in the case of rat species, thiocyanate treatment provoked follicular cell hyperplasia and a decrease in colloid volume. An obvious colloid goiter was also induced in the thyroid of rats exposed to high doses of iodine; the follicles were filled with colloid and the epithelial cells were flattened (Fig. 2). These results were in agreement with the results of Yang et al. ${ }^{(2)}$. This indicated that the model of chronic high doses of iodine exposure was established. The histological aspect of the thyroid glands, after excessive iodine intake in rats exposed to thiocyanate induced hypothyroidism, was improved comparatively to animals of group 2 (thiocyanate induced hypothyroidism), with an increase in colloid volume and a decrease of follicular cell hypertrophy.

Furthermore, the results of the current study showed that lipid peroxidation products (MDA) and antioxidant parameters (glutathione $\mathrm{S}$ transferase, catalase, superoxide dismutase nitric oxide, total antioxidants) were significantly increased in rats with thiocyanate induced hypothyroidism. These results suggested the development of an adaptive response in the antioxidant system of rats within a period of 4 weeks of severe iodine deficiency, caused by thiocyanate, to protect the thyroid against increased oxidative 
stress. It is known that the generation of $\mathrm{H}_{2} \mathrm{O}_{2}$ is inhibited by iodide in vivo and in vitro ${ }^{(5)}$. This implies higher generation of $\mathrm{H}_{2} \mathrm{O}_{2}$ in the thyroid gland in iodine deficiency ${ }^{(43)}$. Giray et al. ${ }^{(44)}$ investigated the antioxidant and oxidant status of thyroid gland in an iodine-deficient rat model. They introduced iodine deficiency by supplying male Wistar rats with $1 \%$ sodium perchlorate-containing water for 5 weeks. Iodine deficiency and the resulting hypothyroidism in rats was evidenced by increased weight of the thyroid gland, higher levels of TSH, and low levels of circulating $\mathrm{T}_{4}$ and $\mathrm{T}_{3}$. Marked changes in antioxidant enzymes (AOE) activities, including 2.5 -fold increase in cGPx, $100 \%$ enhancement in CAT and (although nonsignificant), $50 \%$ increase in SOD, were observed in the thyroid. These results suggested the development of an adaptive response in the $\mathrm{AOE}$ system of rats within a period of 5 weeks of severe iodine deficiency, to protect the thyroid against oxidative stress induced by the high levels of $\mathrm{H}_{2} \mathrm{O}_{2}$ and the derived ROS. Thus, iodine deficiency produces oxidant stress in the thyroid gland and the elevation of thyroidal cGPx, CAT and SOD activities in severely iodine deficient rats seems to provide a compensatory effective means of elimination and control of $\mathrm{H}_{2} \mathrm{O}_{2}$ and the ROS. The data presented in a recent report ${ }^{(14)}$ were also in line with our findings, and supported the hypothesis that although thyrocytes very likely have an effective mechanism to regulate antioxidative response that counter the potential threat of oxidant stress, the compensatory increase in $\mathrm{H}_{2} \mathrm{O}_{2}$, during severe iodine deficiency. The study was conducted on mice and rats fed an iodine-controlled diet, and the time course of adaptive changes was determined. Extracellular SOD, PHGPx and peroxiredoxine 3 and 5 showed increased mRNA expression within 2-3 months of iodine restriction.

Administration of excess iodine, in doses of 3000 and $6000 \mu \mathrm{g} / \mathrm{l}$, to euthyroid or hypothyroid rats caused significant increase in lipid peroxide (MDA), antioxidant enzymes (glutathione $\mathrm{S}$ transferase, catalase, superoxide dismutase), nitric oxide and total antioxidants. Joanta et al. ${ }^{(13)}$ noticed that a high iodine diet induced oxidative stress in the thyroid gland, leading to an increased lipid peroxides level in this tissue. They propose two hypotheses that could explain the mechanism of the oxidative attack: excess iodide has an indirect effect, by altering the thyroid hormones synthesis, and a direct effect exerted on the thyroid gland. Regarding the first hypothesis, a high iodide diet determined an inhibition of thyroid hormones synthesis for a few days, explained through the acute Wolff-Chaikoff effect. After the escape from this phenomenon, a sudden increase in hydrogen peroxide production and thyroid hormones synthesis occurred. Hydrogen peroxide reacted with the polyunsaturated fatty acids from the follicular cell membrane leading to a high level of malondialdehyde in thyroid gland. Because the hydrogen peroxide represents the specific substrate for catalase, an antioxidant enzyme, an increase in hydrogen peroxide production led to an increase 
in catalase activity in order to neutralize this reactive oxygen specie, as it was noticed in our experiment. It is well known that the mitochondria contains specific receptors for the thyroid hormone and it is, also, the place where much of the reactive oxygen species production occurs, via oxidative phosphorylation ${ }^{(45)}$. After the escape from the Wolff-Chaikoff effect, thyroid hormone stimulated hydrogen peroxide production acting on mitochondria. In this way, the oxidative attack in the thyroid gland is emphasized. Furthermore, the thyroid hormone, having prooxidant effect on liver ${ }^{(46)}$, determined an increase in lipid peroxides levels and in catalase activity in this tissue. Also, in the first days, when the Wolff-Chaikoff effect is present and thyroid hormone production is low, a rise could be possible in the thyroid-stimulating hormone (TSH) levels, which directly stimulates the hydrogen peroxide production in the thyroid gland. The second hypothesis that was proposed, regarding the direct oxidative effect of a high iodine diet on the thyroid gland, is sustained by other studies. As already proposed ${ }^{(47)}$, the production of free radicals occurring after administration of a high dose of iodide could overwhelm the normal cellular defenses' against free radicals (e.g. glutathione peroxidase, superoxide dismutase, catalase). This could be explained as follows: when iodide is in excess as compared to tyrosine residues, it reacts with the iodinium cation formed by iodide oxidation to give molecular iodine, which could in turn react with the peroxide to form oxygen-derived free radicals. These radicals would then induce not only lipid peroxidation and thus membrane damage, but also protein and even DNA alterations. All these events could be finally responsible for the cell necrosis by a mechanism dependent on the peroxidase activity and peroxide generation $^{(48)}$.

\section{Conclusion}

1. In rats with thiocyanate induced hypothyroidism, the thyroid is enlarged, thyroid hormones $\left(\mathrm{T}_{3}\right.$ and $\mathrm{T}_{4}$ ) decreased but $\mathrm{T}_{3} / \mathrm{T}_{4}$ ratio increased due to increased D1 deiodinase gene expression that convert more $T_{4}$ to $T_{3}$. Moreover, hypothyroidism induces an oxidative stress and increased gene expression of NIS and TPO.

2. Excess iodide, five or ten folds over the daily physiological intake, given chronically to rats with normal thyroid function for 4 weeks, increases $T_{4}$ and decreases $T_{3}$ due to decreased D1 deiodinase gene expression. In addition, it decreases gene expression of thyroid NIS causing escape from the WolffChaikoff effect as a result of decreased iodide transport into the thyroid which then lowers the intrathyroidal iodine below a critical threshold and would allow organification to resume. On the other hand, administration of excess iodine to hypothyroid rats increases $\mathrm{T}_{4}$ to normal and $\mathrm{T}_{3}$ below normal and decreases gene expression of NIS, D1 deiodinase, and TPO.

3. Moreover, a high iodide intake, to animals with a normal or decreased thyroid function, induces alterations in prooxidant/antioxidant status of thyroid gland. It increases lipid peroxides (MDA) and all 
antioxidant parameters (glutathione $\mathrm{S}$ transferase, catalase, superoxide dismutase enzymes, nitric oxide and total antioxidants).

Therefore, screening of the thyroid function and the assessment of prooxidant/antioxidant status in subjects treated with drugs containing iodine and after investigations with contrast media are recommended.

\section{REFERENCES}

1. Delange $F$ and Lecomte $P$ (2000): Iodine supplementation: benefits outweigh risks. Drug Saf., 22:89-95.

2. Yang XF, Xu J, Hou XH, Guo HL, Hao LP, Yao P, Liu LG and Sun XF (2006): Developmental toxic effects of chronic exposure to high doses of iodine in the mouse. Reproductive Toxicol., 22: 725730.

3. Prakash R (2005): High thyroid volume in children with excess dietary iodine intakes. Am. J. Clin. Nutr., 82:708-9.

4. Delange $F$ (2002): Iodine deficiency in Europe and its consequences: an update. Eur. J. Nucl. Med. Mol. Imaging 29: S404-S416.

5. Morand $S$, Chaaraoui $M$, Kaniewski J, Deme D, Ohayon R, Noel-Hudson MS, Virion A and Dupuy C (2003): Effect of iodide on nicotinamide adenine dinucleotide phosphate oxidase activity and Duox 2 protein expression in isolated porcine thyroid follicles. Endocrinology, 144:1241-1248.
6. Spitzweg $\mathrm{C}$ and Morris JC (2002): The sodium iodide symporter: its pathophysiological and therapeutic implications. Clin. Endocrinol., 57:559-574.

7. Royaux IE, Suzuki K, Mori A, Katoh R, Everett LA, Kohn LD and Green ED (2000): Pendrin, the protein encoded by the Pendred syndrome gene (PDS), is an apical porter of iodide in the thyroid and is regulated by thyroglobulin in FRTL-5 cells. Endocrinology 141:839-845.

8. Carrasco N, Taurog AM, Pisarev MA and Gatner R (2000): Thyroid hormone synthesis. In: Braverman LE, Utiger RD, eds. Werner and Ingbar's the thyroid: a fundamental and clinical text. Philadelphia: Lippincott Williams \& Wilkins; pp: 52-104.

9. De DX, Wang D, Many MC, Costagliola S, Libert F, Vassart G, Dumont JE and Miot F (2000): Cloning of two human thyroid cDNAs encoding new members of the NADPH oxidase family. J. Biol. Chem., 275:23227-23233.

10. Das $K$ and Chainy GB (2001): Modulation of rat liver mitochondrial antioxidant defence system by thyroid hormone. Biochimica Biophysica Acta 1537: 4439-4447.

11. Gerard AC, Many MC, Daumerie C, Knoops $B$ and Colin IM (2005): Peroxiredoxin 5 expression in the human thyroid gland. Thyroid, 15:205-209.

12. Van Sande J, Grenier $C$, Willems C, Dumont JE (1975): Inhibition by iodide of the thyroid 
cyclic

AMP-system.

Endocrinology 96: 781-786.

13. Joanta AE, Filip A, Clichici S, Andrei $S$ and Daicoviciu $D$ (2006): Iodide excess exerts oxidative stress in some target tissues of the thyroid hormones. Acta Physiol. Hung., 93 (4): $347-$ 359.

14. Maier $J$, van Steeg $H$, van Oostrom C, Paschke R, Weiss RE and Krohn K (2007): Iodine deficiency activates antioxidant genes and causes DNA damage in the thyroid gland of rats and mice. Biochimica Biophysica Acta 1773: 990-999.

15. Ghorbel $H$, Fetoui $H$, Mahjoubi A, Guermazi $F$ and Zeghal N (2008): Thiocyanate effects on thyroid function of weaned mice. C. R. Biologies 331: 262-271

16. Fischer PWF, L'Abbe MR and Giroux A (1986): Colorimetric determination of total iodine in foods by iodide-catalyzed reduction of $\mathrm{Ce}^{4+}$. Anal. Chem., 69:687-9.

17. Buege JA and Aust SD (1972): Microsomal lipid peroxidation. Methods Enzymol., 52:302-10.

18. Koracevic D, Koracevic G, Djordjevic V, Andrejevic S and Cosic V (2001): Method for the measurement of antioxidant activity in human fluids. J. Clin. Pathol., 54: 356 - 361.

19. Aebi H (1984): Catalase in vitro. Methods Enzymol., 105: 121 126.

20. Nishikimi M, Roa NA and Yogi K (1972): The occurrence of superoxide anion in the reaction of reduced phenazine methosulphate and molecular oxygen. Biochem. Bioph. Res. Commun., 46:849-854.

21. Habig WH, Pabst MJ and Jacob WB (1974): Glutathione S-transferase. The first enzymatic step in mercapturic acid formation. J. Biol. Chem., 249: 7130-7139.

22. Bulau P, Zakrzewicz D, Kitowska K, Leiper J, Gunther A, Grimminger F, and Eickelberg O (2007): Analysis of methylarginine metabolism in the cardiovascular system identifies the lung as a major source of ADMA. Am. J. Physiol. Lung Cell. Mol. Physiol., 292: L18-L24.

23. Raha $S$, Ling $M$ and Merante $F$ (1998): Extraction of total RNA from tissues and cultured cells. In: Molecular Biomethods Handbook, Replay R, Walker JM (eds), Human Press Inc., Totowa, NJ.Ch.1:pp.1-8.

24. Berchtold MW (1989): A simple method for direct cloning and sequencing cDNA by the use of a single specific oligonucleotide and oligo (dT)in a polymerase chain reaction(PCR). Nucleic Acids Res., 17(1):453.

25. Li HS and Carayanniotis G (2007): Induction of Goitrous Hypothyroidism by dietary iodide in SJL mice. Endocrinology 148(6):2747-2752.

26. Wang K, Sun YN, Liu JY, Yan YQ and Chen ZP (2006): Type 1 iodothyronine deiodinase activity and mRNA expression in rat thyroid tissue with different iodine intakes. Chin. Med. J.,119(22):1899-1903. 
27. Beckers C, Delange F, Gaintan E, Suzuki H, Koutras DA and Medeiros-Neto GA (1980): Etiology of endemic goiter. In: Stanbury JB, Heztel BS, editors. Endemic goiter and endemic cretinism: iodine nutrition in health and disease. New York, NY: John Wiley \& Sons, pp: 237-53.

28. Zhao J, Wang $P$, Shang $L$, Sullivan KM, van der Haar F and Maberly G (2000): Endemic goiter associated with high iodine intake. Am. J. Public Health 90:1633-5.

29. Chen XY, Sun XF, Pang $H$, Yang XF, Yu D, Hou XH, (2005): Acute toxicity and mutagenicity of $\mathrm{KIO}_{3}$. J. Toxicol., 19:129-31.

30. Hetzel BS (2004): The nature and magnitude of the iodine deficiency disorders. In: Hetzel BS, ed. Towards the global elimination of brain damage due to iodine deficiency. England: Oxford University Press, pp: 120.

31. Spitzweg C, Joba W, Eisenmenger $W$ and Heufelder AE (1998): Analysis of human sodium iodide symporter gene expression in extrathyroidal tissues and cloning of its complimentary deoxyribonucleic acids from salivary gland, mammary gland and gastric mucosa. J. Clin. Endocrinol. Metab., 83: 1746-1751.

32. Carrasco N (1993): Iodide transport in the thyroid gland, Biochim. Biophys. Acta 1154: 65-82.
33. Dai G, Levy O, Carrasco $\mathbf{N}$ (1996): Cloning and characterization of the thyroid iodide symporter. Nature 379:458-460.

34. Bastomsky CH (1974): Thyroid iodide transport, in: S.R. Geiger (Ed.), Handbook of Physiology, vol. 3, American Physiological Society, Washington D.C., p.81 (sect. 7).

35. Laurberg $\mathbf{P}$, Pedersen IB, Carlé A, Andersen S, Knudsen $\mathbf{N}$ and Karmisholt J (2009): The Relationship between thiocyanate and iodine. In: Preedy VR, Burrow GN, Watson RR (eds), Academic press, Elsevier Inc., California, USA: pp.275-281.

36. Ohtani $H$ and Rosenberg IN (1971): Prompt stimulation by TSH of thyroid oxidation of thiocyanate, Endocrinology 88 : 566-573.

37. Contempré B, Morreale de Escobar G, Denef JF, Dumont JE and Many MC (2004): Thiocyanate induces cell necrosis and fibrosis in selenium and iodine-deficient rat thyroids: apotetial experimental model for myxedematous endemic cretinism in central Africa. Endocrinology 145:994-1002.

38. Eng PH, Cardona GR and Fang SL (1999): Escape from the acute Wolff-Chaikoff effect is associated with a decrease in thyroid sodium/iodide symporter messenger ribonucleic acid and protein. Endocrinology 140(8): 3404-3410.

39. Markou K, Georgopoulos N, Kyriazopoulou $\mathbf{V}$ and Vagenakis AG (2001): Iodine- 
induced hypothyroidism. Thyroid 11(5): 501-510.

40. Burgi H (2010): Iodine excess. Best Practice \& Research Clinical Endocrinology \& Metabolism 24:107-115.

41. Kocova $M$, Netkov $S$ and Sukarova-Angelovska E (2001): Pituitary pseudotumor with unusual presentation reversed shortly after the introduction of thyroxine replacement therapy, J. Pediatr. Endocrinol. Metab., 14: 1665-1669.

42. Soussia L, Ben Hamida F, Guermazi $F$ and Zeghal N (2004): Induction and reversibility of action of thiocyanate on the thyroid function in the rat in period of breast feeding. Ann. Endocrinol., 65:451-458.

43. Hincal F (2009): Oxidative Damage in Iodine Deficiency. In: Preedy VR, Burrow GN, Watson RR (eds.), Academic press, Elsevier Inc., California, USA: pp.487-497.

44. Giray B, Riondel J, Richard MJ, Favier $A$ and Hincal $F$ (2004): Oxidant/antioxidant status in relation to thyroid hormone metabolism in seleniumand/or iodine-deficient rats. J. Trace Elem. Exp. Med., 17, 109121.
45. Vendit ti P, Balestrieri M, Di Meo $S$ and De Leo T (1997): Effect of thyroid state on lipid peroxidation, antioxidant defenses and susceptibility to oxidative stress in rat tissues. Endocrinol., 155:151- 157.

46. Joanta A, Filip A, Clichici S, Suciu $S$ and Dorofteiu $M$ (2003): Modulation of rat liver prooxidant/antioxidant balance by thyroid hormones. Physiology (Romanian J. of Physiol.), 1(37): 12-17.

47. Many MC, Papadopoulos J, Martin C, Colin I, Denef JF (1992): Iodine induced cell damage in mouse hyperplastic thyroid is associated to lipid peroxidation. In: Progress in Thyroid research. eds Gordon A, Gross J, Hennermann G. Proceedings of the 10th International Thyroid Conference, The Hague A.A. Balkema Publishers, Rotterdam. pp. 635638.

48. Kohler H, Taurog $A$ and Dunford HB (1988): Special studies with lactoperoxidase and thyroid peroxidase: interconversions between native enzyme, compound II, and compound III. Arch. Biochem. Biophys., 264:438-449. 


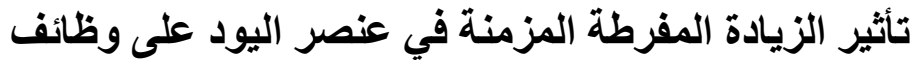

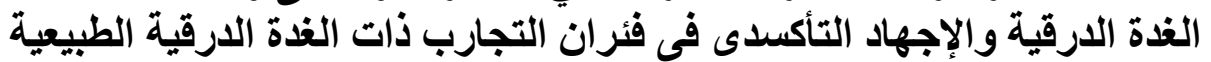
و قاصرة الوظائف

\author{
عمرو ملحت عباس '؛عب العزيز حسين '؛جيهان الوكيل'؛

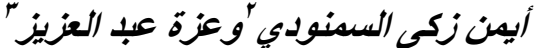

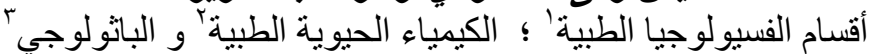 \\ كلية الطب - جامعة المنصورة الكياء الكية
}

الهدف من هذا البحث هو دراسة تأثثر الزيادة المفرطة المزمنة في عنصر اليود على التعبير الجينى لجينات sodium iodide symporter (NIS)-D1 deiodinase-thyroid peroxidase (TPO)

وظائف الغدة الدرقية ونو اتج الأكسدة (ثنائى الدهيد المالون) و مضادات البات الأكسدة بالغدة الدرقية.

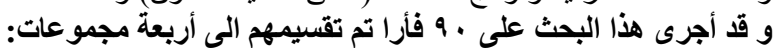

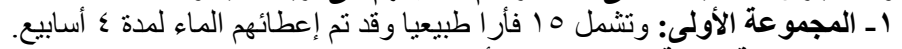

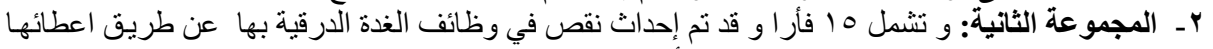

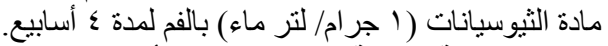

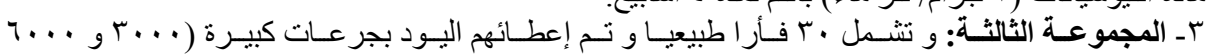

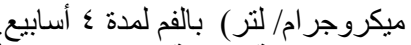

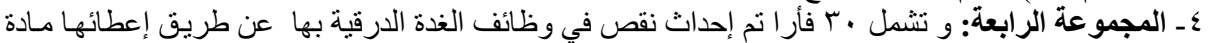

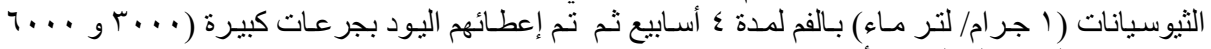

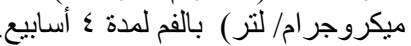
و قد تم أخذ عينات دم و بول كما تم استئصسال الغدة الدرقيـة من كل الفئران و تم عمل الفحوصـات الآتية لكل

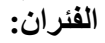
اـ قياس التعبير الجينى لجينـات Sympodium iodide symporter (NIS)-D1 deiodinase-thyroid peroxidase (TPO)

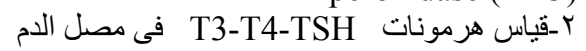
كـ قياس نو اتج الاكسدة (ثنائى الدهيد المالون) و وضئ مضادات الأكسدة بمستخلص الغدة الدرقية

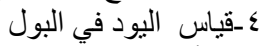

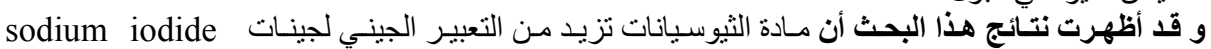
symporter (NIS)-D1 deiodinase-thyroid peroxidase (TPO)

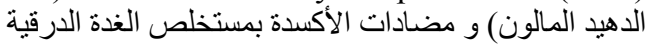

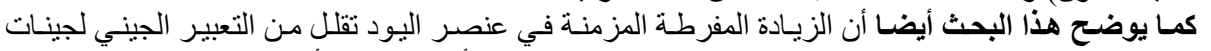
sodium iodide symporter (NIS)-D1 deiodinase و مضادات الأكسدة بمستخلص الغدة الدرقية

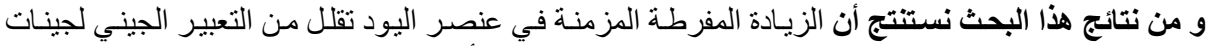
و sodium iodide symporter (NIS)-D1 deiodinase

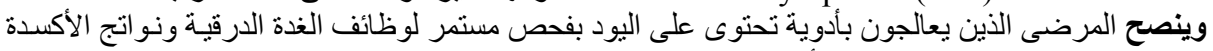

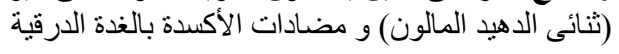

